Article

\title{
Quality and Storability of Trellised Greenhouse-Grown, Winter-Harvested, New Sweet Acorn Squash Hybrids
}

\author{
Ayobami Adeeko 1,2® ${ }^{1}$, Fabiola Yudelevich ${ }^{1}$, Ginat Raphael ${ }^{1}$, Lior Avraham ${ }^{3}$, Hana Alon ${ }^{4}$, \\ Merav Zaaroor Presman ${ }^{1}$, Sharon Alkalai-Tuvia ${ }^{1}$, Harry S. Paris ${ }^{5}$, Elazar Fallik ${ }^{1} \mathbb{D}$ and \\ Carmit Ziv ${ }^{1, *(\mathbb{D})}$ \\ 1 Department of Postharvest Science, Agricultural Research Organization, Volcani Center, \\ Rishon LeZiyyon 7505101, Israel; ayobami.adeeko@mail.huji.ac.il (A.A.); fabiolay@volcani.agri.gov.il (F.Y.); \\ pongie@volcani.agri.gov.il (G.R.); merav.zaaroor@mail.huji.ac.il (M.Z.P.); sharon@volcani.agri.gov.il (S.A.-T.); \\ efallik@volcani.agri.gov.il (E.F.) \\ 2 The Robert H. Smith, Faculty of Agriculture, Food and Environment, P.O. Box 12, Rehovot 7610001, Israel \\ 3 Agricultural Extension Service of the Ministry of Agriculture, Bet Dagan 50250, Israel; \\ lior.avraham@gmail.com \\ 4 Southern Research \& Development, Besor Experiment Station, Mobile Post Office Negev 4 85400, Israel; \\ hana@mopdarom.org.il \\ 5 Newe Ya'ar Research Center, Agricultural Research Organization, P.O. Box 1021, \\ Ramat Yishay 3009500, Israel; hsparis@volcani.agri.gov.il \\ * Correspondence: Carmit.Ziv@volcani.agri.gov.il; Tel.: +972-3-9683610
}

Received: 20 August 2020; Accepted: 17 September 2020; Published: 22 September 2020

\begin{abstract}
Acorn squash (Cucurbita pepo) is a familiar fruit vegetable in North America, appreciated for its attractive appearance, good flavor, nutritional content and long storage life. A breeding program in Israel has produced three new acorn squash hybrids of enhanced sweetness and flavor. Presently, we evaluated productivity, quality, and storability of these new cultivars in fall plantings. The plants were grown trellised, in an insect-proof greenhouse, for fruit production during the winter to meet consumer demand. The plants were highly productive and bore fruits of superb quality, but there was a high incidence of fungal rots during postharvest cold storage. Pre-treating the fruits with hot water brushing and rinsing before storage was found effective in reducing rot incidence of the fruits stored at $15{ }^{\circ} \mathrm{C}$, but only for one cultivar. Storing the fruits at $10{ }^{\circ} \mathrm{C}$ with reduced humidity $(\mathrm{Rh} 70 \%)$ enabled a 3-month shelf life with significantly reduced fruit-rot incidence and minimal effect on fruit quality of all three cultivars. Storage at $20^{\circ} \mathrm{C}$ with reduced humidity was suitable for a 1-month period. These protocols for prolonging storage life will help attain controlled, gradual year-round marketing of quality acorn squash at uniform, reasonable price levels for farmers and consumers, and could facilitate overseas export.
\end{abstract}

Keywords: Cucurbita pepo; winter squash; protected cultivation; fruit quality; prolonged storage; fruit decay; anti-fungal treatment

\section{Introduction}

Acorn squash, Cucurbita pepo subsp. texana Acorn Group, is a familiar produce item in the United States and Canada. Acorn squash were developed by Native North Americans in pre-Columbian times [1,2]. Mature acorn squash are rather small, usually ranging from 250 to $1000 \mathrm{~g}$ in weight and are turbinate, with distinct alternating ridges and furrows [3]. The external color of acorn squash cultivars varies widely, in shades of green, yellow, and orange, from nearly black to nearly white, and can be 
longitudinally striped and or latitudinally bicolor. Most commonly, though, they are dark green. When well grown and allowed to ripen fully, acorn squash have a pleasing flavor and a soluble solids content of $8-11 \%[4,5]$.

Fruits of acorn squash reach their maximum size at approximately 20 days past anthesis (dpa) $[4,5]$. Accumulation of dry matter, mostly starch, in the mesocarp (fruit flesh) occurs in parallel with increase in fruit size and then continues for approximately 20 more days, until 35-40 dpa. By $40 \mathrm{dpa}$, dry matter content of the mesocarp begins to decrease, coinciding with late stages of embryo development and seed fill. As seed fill is occurring, starch is converted to sugars. Dry matter content in acorn squash fruit flesh usually reaches a maximum between 12 to $20 \%$. This modest dry matter content is not high enough to assure good eating quality and consistency of the cooked squash.

During storage of acorn squash, sugar content of the mesocarp tends to increase and high sugar levels are much preferred by consumers, but starch content decreases, resulting in a thinner, looser, more fibrous consistency of the fruit flesh [5]. Moreover, large commercial growers tend to harvest acorn squash at approximately $30 \mathrm{dpa}$ or even earlier, long before they have achieved maximum sweetness. Squash harvested at this stage will have approximately $7 \%$ total soluble solids content, too low to have acceptable palatability, but if stored for three weeks, can reach an acceptable level of $10 \%$. However, if the dry matter content of the squash at harvest is only around $15 \%$, then its conversion to sugar in storage will result in the fruit flesh having an unacceptable thin, loose, fibrous consistency upon cooking.

Over the past few decades at the Agricultural Research Organization in Israel, efforts were devoted to developing a much improved acorn squash [6,7]. The efforts focused on introgressing four characteristics: (1) Black-green fruit color replaced dark green, for a more attractive appearance; this replacement proved to be more important than realized at first, by increasing the longevity after harvest of the green hue and by its seeming association with a distinct, roasted chestnut flavor imparted to the fruit flesh. (2) Bushy growth habit replaced viney growth habit. (3) Plant resistance to powdery mildew was introgressed from a straightneck squash. (4) Increased sweetness of the fruit flesh was introgressed from germplasm developed by J.R. Baggett at Oregon State University. These efforts resulted in the release of Acorn Hybrid 1700, named 'Table Sugar', in 2007. The plants of this new cultivar are bushy and resistant to powdery mildew, and its fruits are small, averaging $350 \mathrm{~g}$, with a black-green exterior and fruit-flesh soluble solids content ranging from 12-18\%. A decade later, the larger fruited Acorn Hybrid 2005, named 'Table Confection', and Acorn Hybrid 2054, named 'Table Pastry', were released.

Since its release in 2007, 'Table Sugar' has been produced mostly in the open field, in late winter to late spring plantings [6]. The fruits were harvested and offered for sale from May until July. As consumers became familiar with this premium product, demand grew for a continuous year-round supply. However, summer and fall plantings were not practical due to high virus pressure vectored by whiteflies, Bemisia tabaci, and winters too cool for production in the open field. Covered (protected) cultivation is highly effective in preventing virus infection, a major threat to cucurbits all over the world [8] and the possibility of growing 'Table Sugar' acorn squash in netted greenhouses during the winter has been explored. An experimental trellised growth of acorn squash in protected greenhouses covered with 50 mesh insect-proof nets has enabled a long growth period for planting in the late summer or fall (August and September) and harvesting in the winter, thereby providing both, heat and protection against viruses (Avraham and Ziv, unpublished).

In late winter and early spring, there is a market shortage of 'Table Sugar' and the prices are very high, reaching approximately US $\$ 12.50$ per $\mathrm{kg}$. Late summer- and fall-planted acorn squash, which bear in winter, would require storage in order to enable their marketing during the peak period of prices in the spring. In order to ensure stable and profitable marketing of acorn squash during this period, an adequate management of postharvest diseases is required. Previous work evaluated postharvest treatments and storage conditions of summer, field-grown 'Table Sugar' acorn squash and determined that storage at $15^{\circ} \mathrm{C}$ after hot water rinsing and brushing can enable long-term storage of 
these fruits with only mild effects of fruit quality [9]. However, the trellised, protected cultivation in the fall and winter has called for a complete re-evaluation of this storage protocol. The current work is the first to systematically evaluate and compare the productivity, fruit quality and storability of trellised greenhouse-grown, winter-produced, sweet acorn squash and presents an optimal protocol for their storage.

\section{Materials and Methods}

\subsection{Plant Materials}

Experiments were conducted with acorn squash fruits of 'Table Sugar' (Hybrid 1700), 'Table Confection' (Hybrid 2005), and 'Table Pastry' (Hybrid 2054). Seeds were obtained from Origene Seeds (Giv'at Brenner, Israel).

\subsection{Growing Conditions}

Acorn squash plants, approximately 17 days after seeding in trays in a commercial facility, were transplanted into a netted greenhouse covered with 50 mesh insect-proof netting at the Besor Experiment Station in southwestern Israel $\left(31^{\circ} 16^{\prime} 20^{\prime \prime} \mathrm{N}, 34^{\circ} 23^{\prime} 15^{\prime \prime} \mathrm{E}\right)$. The transplants were laid into the sandy soil $40 \mathrm{~cm}$ apart in a single row, with $2 \mathrm{~m}$ spacing between rows. This resulted in a population density of 1250 plants per 1000 square meters. Each cultivar was planted in four plots of a randomized complete block, each plot being $10 \mathrm{~m}$ long and containing 25 plants, for a total 100 plants per cultivar. During the growing period, the plants were supported for vertical growth using Dutch trellising (Figure 1).

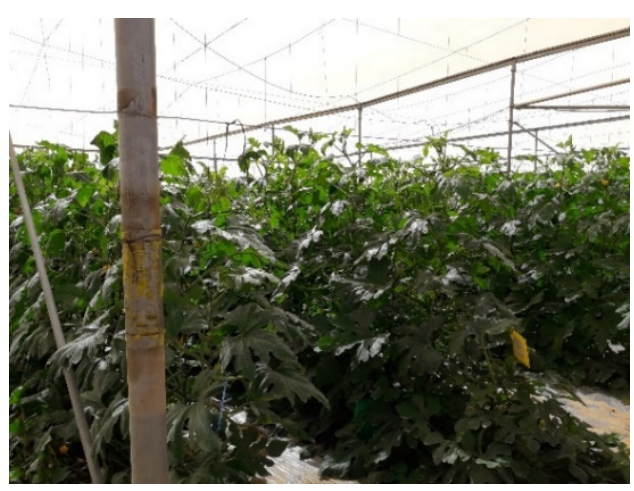

(a)

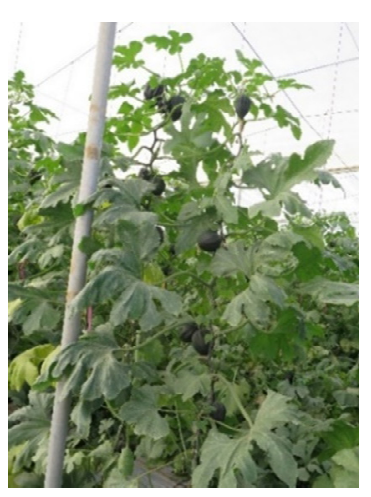

(b)

Figure 1. (a) Trellised growth of acorn squash in the netted greenhouse. (b) Fruit load on a trellised plant.

The experiments were performed in three consecutive years beginning in 2017 (Table 1). For the first two years, two-and-a-half week-old seedlings were transplanted during September. The third experiment was transplanted in August. During all seasons, pollination was performed by bumblebees (genus Bombus), and three harvests of fruits were performed after 2-5 months of growth (Table 1).

\subsection{Experiments and Treatments}

\subsubsection{Harvesting}

Over the course of each of the three years of the experiment, fruits of all three cultivars together set, developed, and ripened in three cycles. Therefore, three harvests were performed for each experiment. Fruits from the same fruit-set cycle were therefore fit for comparison and were harvested from the three cultivars simultaneously. The timing of the harvest was determined by fruit size (when reaching full size) followed by cutting open 8-10 randomly selected fruits from the entire greenhouse to assess the maturity of the seeds and the color of the fruit flesh. Evaluations of fruit quality were performed 
for all harvests of 2017, the first and the second harvests of 2018, and the second and third harvests of 2019 (Table S1). On the day of harvest, fruit weight and rind color were assessed for all fruits. Flesh color, fruit firmness, TSS, and dry weight were assessed for 6-8 fruits of each cultivar.

Table 1. Milestone dates for the three seasons.

\begin{tabular}{|c|c|c|c|c|c|}
\hline & $\begin{array}{c}\text { Transplanting } \\
\text { Date }\end{array}$ & $\begin{array}{l}\text { Introduction } \\
\text { of Bumblebees } \\
\text { for Pollination }\end{array}$ & $\begin{array}{c}\text { First } \\
\text { Harvest }\end{array}$ & $\begin{array}{l}\text { Second } \\
\text { Harvest }\end{array}$ & Third Harvest \\
\hline \multirow{2}{*}{ First Year } & 26 September & 19 October & 25 December & 16 January & 07 February \\
\hline & 2017 & 2017 & 2017 & 2018 & 2018 \\
\hline \multicolumn{2}{|c|}{ Days from planting } & & 90 & 112 & 134 \\
\hline Second & 17 September & 07 October & 10 December & 15 January & 20 February \\
\hline Year & 2018 & 2018 & 2018 & 2019 & 2019 \\
\hline \multicolumn{2}{|c|}{ Days from planting } & & 84 & 120 & 156 \\
\hline Third Year & $\begin{array}{l}05 \text { August } \\
2019\end{array}$ & $\begin{array}{l}29 \text { August } \\
2019\end{array}$ & $\begin{array}{l}10 \text { October } \\
2019\end{array}$ & $\begin{array}{c}06 \\
\text { November } \\
2019\end{array}$ & $\begin{array}{l}20 \text { November } \\
2019\end{array}$ \\
\hline \multicolumn{3}{|c|}{ Days from planting } & 66 & 93 & 107 \\
\hline
\end{tabular}

\subsubsection{Postharvest Handling}

After harvest, the fruits were washed by tap water rinsing and brushing (TWRB) or hot water rinsing and brushing (HWRB, see below) in a designed sprinkler system, air-dried, and stored in boxes. After washing, each fruit was numbered and weighed before storage. Overall, 600 fruits were evaluated in the first year, 700 fruits were evaluated in the second year and 400 fruits were evaluated in the third year of the experiment.

\subsubsection{Hot Water Rinsing and Brushing Treatment}

Fruits treated with $\operatorname{HWRB}\left(54 \pm 1{ }^{\circ} \mathrm{C}\right.$ for $\left.15 \mathrm{~s}\right)$ were air-dried and then stored at $15{ }^{\circ} \mathrm{C}$ [9]. The treatment was applied to 30 fruits of each cultivar from the three harvests, during the first year of the experiment (90 fruits for each cultivar). The treatment was not evaluated during the next years of the experiment due to its inefficacy in preventing fruit deterioration during storage.

\subsubsection{Storage Conditions}

The treated fruits as well as control untreated fruits were stored at $15{ }^{\circ} \mathrm{C}$ and $95 \% \mathrm{Rh}$, as recommended by Chalupowicz et al. [9]. During the second and third year, untreated fruits were stored in an additional three conditions (Table 2), with at least 20 fruits of each cultivar per harvest stored in each condition. The temperature and relative humidity during storage were constantly monitored by a data logger (EL-USB-2, Lascar Electronics, Whiteparish, UK). To obtain the low-humidity atmosphere at $10^{\circ} \mathrm{C}$ for the "10 deg $\mathrm{Rh} 70 \%$ ", a drier controlled by a humidity sensor was placed in the storage room.

Table 2. Storage conditions and duration during the second and third years of experimentation.

\begin{tabular}{cccc}
\hline Treatment Name & Temperature $\left({ }^{\circ} \mathbf{C}^{\mathbf{1}}\right.$ & Humidity (\% Rh) $^{\mathbf{1}}$ & Storage Period (Days) $^{\mathbf{2}}$ \\
\hline $20^{\circ} \mathrm{C} \mathrm{Rh} 60 \%$ & $19.1 \pm 0.6$ & $60.1 \pm 4.3$ & $56 \pm 3$ \\
$15^{\circ} \mathrm{C} \mathrm{Rh} 95 \%$ & $14.6 \pm 0.4$ & $95.3 \pm 3.6$ & $85 \pm 5$ \\
$10^{\circ} \mathrm{C}$ Rh $95 \%$ & $10.2 \pm 0.3$ & $94.0 \pm 0.6$ & $84 \pm 6$ \\
$10^{\circ} \mathrm{C} \mathrm{Rh} 70 \%$ & $9.6 \pm 0.3$ & $67.0 \pm 2.6$ & $91 \pm 4$ \\
\hline
\end{tabular}

\footnotetext{
${ }^{1}$ Recorded every $30 \mathrm{~min}$ for the entire storage period. Rh, relative humidity. Values presented are the averages \pm standard deviations. ${ }^{2}$ calculated as the average days of storage of the 4-6 repeats ( 2 stored harvests over 2-3 years). Values presented are the averages \pm standard deviations.
} 
The stored fruits were routinely evaluated for rots during the storage period. Rotting fruits were documented and discarded to prevent contamination of neighboring fruits. The cumulative data of the infected/rotting fruits is reported.

\subsection{Fruit Quality Evaluation}

Several parameters indicative of fruit quality were measured at the beginning and at the end of the storage period:

Weight loss Fruits were weighed on the day of harvest (prior to storage, $W_{0}$ ) and at the end of the cold storage period (final weight, $W_{x}$ ). In addition, fruit weight was measured at different time points during the storage period. Statistical analysis was performed for each storage period, separately. Weight loss was calculated using this formula (1):

$$
\% \text { Weight loss }=\frac{W_{0}-W_{x}}{W_{0}} \times 100
$$

Rind Color: Fruit epidermal color before storage $(t=0)$ and at the end of storage was evaluated quantitatively for all fruits using a Chromometer CR-400/410 (Konica Minolta, Osaka, Japan). Two measurements at the blossom (stylar) end area of each fruit were taken, and the results are expressed as Hue angle $\left(\mathrm{Hue}^{\circ}\right)$.

Total soluble solids (TSS): Samples of fruit flesh were frozen overnight and thawed. The fruit flesh samples were squeezed and their juice thereby extracted onto a Palette Digital Refractometer PR-1 (Model DBX-55, Atago, Tokyo, Japan), with 6-8 fruits per treatment before and after storage. The results are expressed at percent TSS.

Dry weight (DW): The fruits were peeled and the fruit flesh cut into pieces $3-5 \mathrm{~mm}$ wide. The exact weight of an approximately $10 \mathrm{~g}$ piece of the fresh tissue $\left(W_{F}\right)$ was recorded and the piece placed on an aluminum plate. The sample was dried in an oven at $55^{\circ} \mathrm{C}$ for 3 days. The weight of the dried sample was taken $\left(W_{D}\right)$. The DW was determined by using the following formula (2):

$$
\% \text { Dry weight }=\frac{W_{D}}{W_{F}} \times 100
$$

Flesh color: Fruit-flesh color was quantified before storage and at the end of the storage period for 6-8 fruits per treatment/repeat using a Chromometer CR-400/410 (Konica Minolta, Osaka, Japan). Fruits were cut equatorially at the approximate middle of the length of the fruit and measurements of flesh color were taken from three approximately equidistant points. The results were calculated as color space value $\mathrm{a}^{*}$, that was shown to be correlated to total carotenoid content in pumpkins and squash [10].

External firmness: Fruit firmness was determined for 6-8 fruits per treatment/repeat before storage and at the end of the storage period. Measurements were performed using a motorized Chatillon penetrometer equipped with a 6-mm conic plunger (John Chatillon \& Sons, Kew Gardens, NY, USA); Firmness was determined at two points for each fruit; each measurement was applied on opposite sides of the fruits, at the equatorial region, and the data were recorded in Newtons $(\mathrm{N})$. Since this is a destructive measurement, these fruits were then used for determining pulp color and for extracting the juice for TSS assay (as described above).

Decay: Fruits were visually inspected for signs of mold (hyphae or conidia). Fruits were considered to be decayed as soon as rot became visible. Decay is reported as percent infected fruits.

Taste: Taste was evaluated using hedonic analysis to check sweetness, bitterness, texture, and overall acceptance by 28-30 untrained people. The fruit flesh (pieces of $5 \mathrm{~g}$, without peel and seeds) were cooked for $4 \mathrm{~min}$ under full power in a microwave oven. Cooked pieces of four fruits per treatment were mixed in one plate. Each tasting experiment included six treatments (three cultivars at two storage conditions). Each taste test was performed twice, for fruits from two different harvests. 


\subsection{Carotenoid Identification and Quantification}

Carotenoid extraction was performed using established protocols [11-13]. In short, $0.5 \mathrm{~g}$ fresh tissue was ground under liquid nitrogen. Carotenoids were extracted and analyzed by HPLC to identify the carotenoids in the fruit flesh of 10 fruits of the three acorn squash cultivars. The absorbance of the extract was measured at $455 \mathrm{~nm}$ for determining $\beta$-carotene content.

\subsection{Statistical Analysis}

Three postharvest experiments during the first year and two postharvest experiments during the second and third years were conducted. In each experiment, each treatment consisted of 2 cartons, with 10-15 fruits per carton (20-30 fruits per treatment), for two repetitions per treatment. All data were subjected to Tukey-Kramer tests by one- or two-tailed ANOVA from 0.05 to 0.0001 , with the JMP-14 Statistical Analysis Software Program (JMP ${ }^{\circledR}$ Pro 14.1, SAS Institute Inc, Cary, NC, USA). Significance was set at $p \leq 0.05$.

\section{Results}

\subsection{Productivity and Fruit Quality of the Three Cultivars}

Trellis cultivation in an insect-proof greenhouse of the three acorn squash cultivars resulted in a high quality fruits. At harvest, the fruits were uniformly black-green (Figure 2), without the orange ground spot developed on prostrate, field-grown plants.
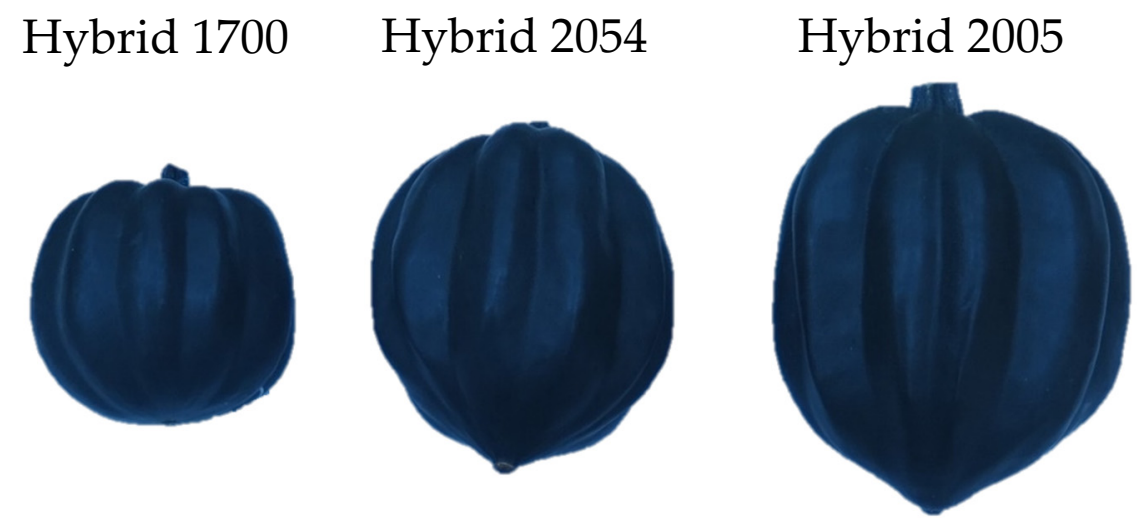

Figure 2. Fruits of the three tested cultivars harvested from trellis-grown plants.

\subsubsection{Yield and Yield Components}

Among the three acorn squash hybrids, yields of 'Table Confection' (Hybrid 2005) were the highest (Table 3). Hybrid 2005 produced $3.2 \mathrm{~kg} / \mathrm{m}^{2}$, which was approximately $60 \%$ more than 'Table Sugar' (Hybrid 1700). Yields of 'Table Pastry' (Hybrid 2054) were intermediate. The three hybrids produced similar numbers of fruits, averaging more than 4 per plant and thus the major component affecting yield was fruit size. Fruits of Hybrid 2005 averaged $572 \mathrm{~g}$ as compared with those of Hybrid 1700, which averaged $353 \mathrm{~g}$. Fruits of Hybrid 2054 averaged $429 \mathrm{~g}$.

Over the three years, fruits of the third harvest tended to be smaller than those of the first two harvests (Figure S1). However, there was no clear trend over the three years concerning yield among the three harvest times (Figure S2).

\subsubsection{Fruit Quality}

The rind color of the trellised acorn squash was uniformly black-green at harvest (Figure 2), but differed to some extent among cultivars and harvests (Table S1). Hybrid 2005 had a rind that was even blacker than the other two cultivars. For all cultivars, rind color was slightly lighter in later harvests. 
Table 3. Fruit size and yield for the three acorn squash cultivars during each growing season.

\begin{tabular}{|c|c|c|c|c|}
\hline Year/Hybrid $X$ & $\begin{array}{l}\text { Average } \\
\text { Fruit Size } \\
\text { (g) }\end{array}$ & $\begin{array}{l}\text { Average Fruit } \\
\text { Circumference } \\
\text { (cm) }\end{array}$ & $\begin{array}{l}\text { Average Number } \\
\text { of Fruits per Plant } \\
\text { (No.) }\end{array}$ & Yield $\left(\mathrm{kg} / \mathrm{m}^{2}\right)$ \\
\hline \multicolumn{5}{|l|}{2017} \\
\hline 1700 & $370 \mathrm{~cd}$ & $27.0 \mathrm{~b}$ & $4.5 \mathrm{a}$ & $1.72 \mathrm{c}$ \\
\hline 2054 & $461 \mathrm{bcd}$ & $29.8 \mathrm{~b}$ & $4.4 \mathrm{a}$ & $2.04 \mathrm{bc}$ \\
\hline 2005 & $715 \mathrm{a}$ & $35.2 \mathrm{a}$ & $3.7 \mathrm{a}$ & $2.73 \mathrm{ab}$ \\
\hline \multicolumn{5}{|l|}{2018} \\
\hline 1700 & $348 \mathrm{~d}$ & $28.3 \mathrm{~b}$ & $5.0 \mathrm{a}$ & $2.16 \mathrm{bc}$ \\
\hline 2054 & $410 \mathrm{bcd}$ & $29.8 \mathrm{~b}$ & $5.2 \mathrm{a}$ & $2.86 \mathrm{ab}$ \\
\hline 2005 & $502 \mathrm{~b}$ & $33.2 \mathrm{a}$ & $4.9 \mathrm{a}$ & $3.40 \mathrm{a}$ \\
\hline \multicolumn{5}{|l|}{2019} \\
\hline 1700 & $340 \mathrm{~d}$ & n.d. y & $4.8 \mathrm{a}$ & $2.02 \mathrm{bc}$ \\
\hline 2054 & $416 \mathrm{bcd}$ & n.d. & $4.4 \mathrm{a}$ & $2.37 \mathrm{bc}$ \\
\hline 2005 & 498 b & n.d. & $4.9 \mathrm{a}$ & $3.48 \mathrm{a}$ \\
\hline LSD & 43.3 & 1.0 & 0.48 & 0.256 \\
\hline \multicolumn{5}{|c|}{ Mean values at each year } \\
\hline 2017 & $515.4 \mathrm{a}$ & $30.7 \mathrm{a}$ & $4.2 \mathrm{~b}$ & $2.17 \mathrm{~b}$ \\
\hline 2018 & $420.0 \mathrm{~b}$ & $30.4 \mathrm{a}$ & $5.0 \mathrm{a}$ & $2.80 \mathrm{a}$ \\
\hline 2019 & $417.7 \mathrm{~b}$ & n.d. & $4.7 \mathrm{ab}$ & $2.62 \mathrm{a}$ \\
\hline $\operatorname{LSD}^{\mathrm{z}}$ & 24.5 & 0.55 & 0.28 & 0.148 \\
\hline \multicolumn{5}{|c|}{ Mean values of each cultivar } \\
\hline 1700 & $352.5 c$ & $27.6 \mathrm{c}$ & $4.7 \mathrm{a}$ & $1.97 \mathrm{c}$ \\
\hline 2054 & $429.0 \mathrm{~b}$ & $29.8 \mathrm{~b}$ & $4.7 \mathrm{a}$ & $2.42 \mathrm{~b}$ \\
\hline 2005 & $571.7 \mathrm{a}$ & $34.2 \mathrm{a}$ & $4.5 \mathrm{a}$ & $3.20 \mathrm{a}$ \\
\hline LSD & 24.5 & 0.68 & 0.28 & 0.148 \\
\hline \multicolumn{5}{|c|}{ Table of Variance (F-value) } \\
\hline Year $(Y r)$ & $* * *$ & NS & * & $* * *$ \\
\hline Cultivar (Cv) & $* * *$ & $* * *$ & NS & $* * *$ \\
\hline Yr $\times$ Cv & $* *$ & NS & NS & NS \\
\hline
\end{tabular}

Fruit firmness at harvest was determined for fruits of two harvests of 2017 and of 2018. Similar to rind color, fruit firmness was significantly dependent on the harvest and cultivar (Table S1). Specifically, fruits of Hybrid 1700 were firmer than those of the other cultivars.

Fruit internal quality varied among the three cultivars but also among harvests (Table S1). Two harvests (the second harvests of 2017 and 2018) were delayed due to weather conditions, resulting in fully ripe fruits with TSS above 18\%. On average, fruit TSS of Hybrid 2005 at harvest was lower than that of Hybrid 1700 and Hybrid 2054. Similarly, the percent dry weight (DW) of Hybrid 2005 was lower than that of the other two (Table S1). The DW of fruits at harvest ranged mostly between 15 to $30 \%$ and showed a highly significant positive correlation with fruit TSS (Figure 3).

The major carotenoid in ripe fruits of all three cultivars was identified as $\beta$-carotene (Figure S3a). Fruit flesh color measured as color space $\mathrm{a}$ * (Figure 4 ) positively and significantly correlated with carotenoid level (Figure S3b). At harvest, pulp a * was significantly lower for Hybrid 2054 (Table S1), indicating a reduced level of carotenoids for fruits of this cultivar. 


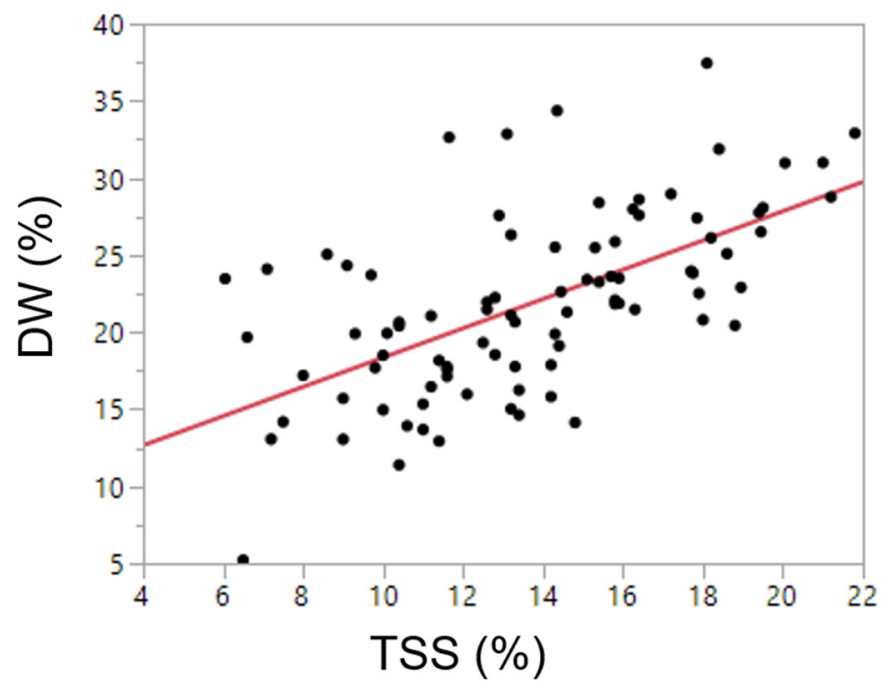

Figure 3. Correlation between total soluble solids (TSS) and percent dry weight (DW) in acorn squash fruit flesh at the time of harvest $(n=90, r=0.607, p<0.0001)$.
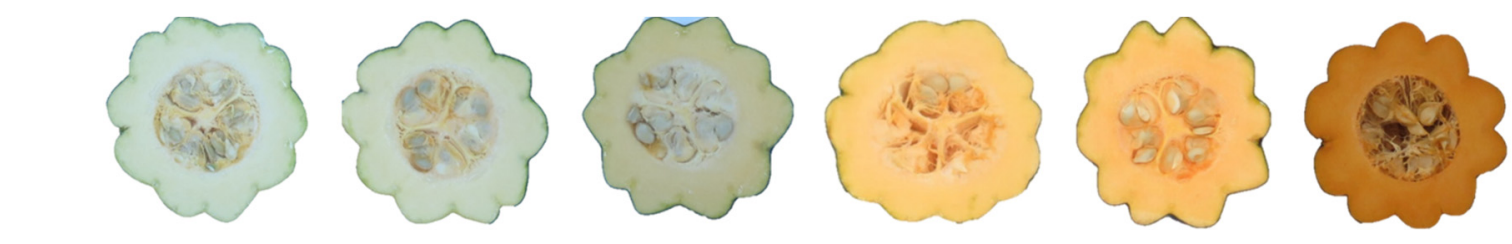

Pulp a*

$<-2$

-2 to 1

1 to 4

4 to 7

7 to 10

$>10$

Figure 4. Pulp color a * measured for fruits with different levels of carotenoids.

\subsection{Storability of the Cultivars}

\subsubsection{Fruit Decay during Storage}

Fruits harvested during the first year were stored at $15{ }^{\circ} \mathrm{C}, \mathrm{Rh} 95 \%$. Already after 2 months of storage, a very high rate $(>30 \%)$ of fruit decay was observed (Figure 5$)$. The infection usually started at the stem, as indicated by the appearance of fungal hyphae and conidia and subsequently, on average, $70 \%$ of these fruits developed stem rot. Fruits of all three cultivars were highly susceptible to fungal molds causing fruit rotting in storage. HWRB treatment significantly reduced decay incidence of Hybrid 1700 to less than $10 \%$ fruit loss. HWRB treatment was not effective in minimizing fruit loss due to fungal infections of Hybrid 2054, which was highly susceptible to fruit decay, as well as to the less susceptible Hybrid 2005.

To evaluate the effect of storage conditions on fruit quality of the three cultivars, untreated fruits from 4 harvests, during the second and third year, were stored at $10{ }^{\circ} \mathrm{C} \mathrm{Rh} 95 \%, 10{ }^{\circ} \mathrm{C} \mathrm{Rh} 70 \%$ and $20{ }^{\circ} \mathrm{C} \mathrm{Rh} 60 \%$ in addition to $15{ }^{\circ} \mathrm{C} \mathrm{Rh} 95 \%$ (Table 1 ). Storage conditions significantly affected fruit decay incidence (Figure 6). Storing the fruits at $10{ }^{\circ} \mathrm{C} \mathrm{Rh} 95 \%$ resulted in a complete loss of the fresh produce. Reducing the humidity of the cold storage to $\mathrm{Rh} 60 \%$ or $70 \%$, at either 10 or $20^{\circ} \mathrm{C}$, significantly reduced fruit decay incidence. 


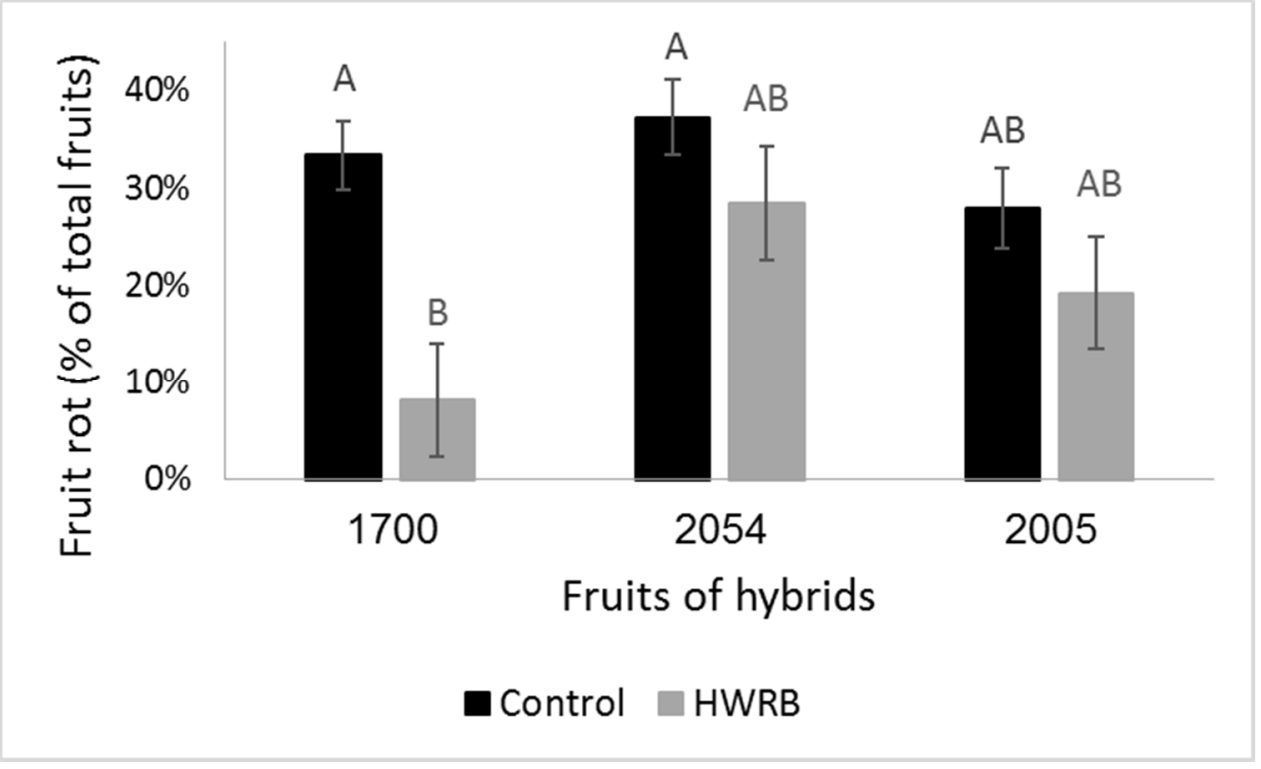

Figure 5. Fruit decay during cold storage at $15{ }^{\circ} \mathrm{C} \mathrm{Rh} 95 \%$. Rot incidents were recorded weekly. Cumulative data of 2 months of storage are presented. Each experiment was conducted 3 times (with fruits of three different harvests), each experiment included 2 repeats for each treatment. Bars indicate standard error. Means without a common letter are significantly different (Tukey HSD, $\alpha=0.05$ ).

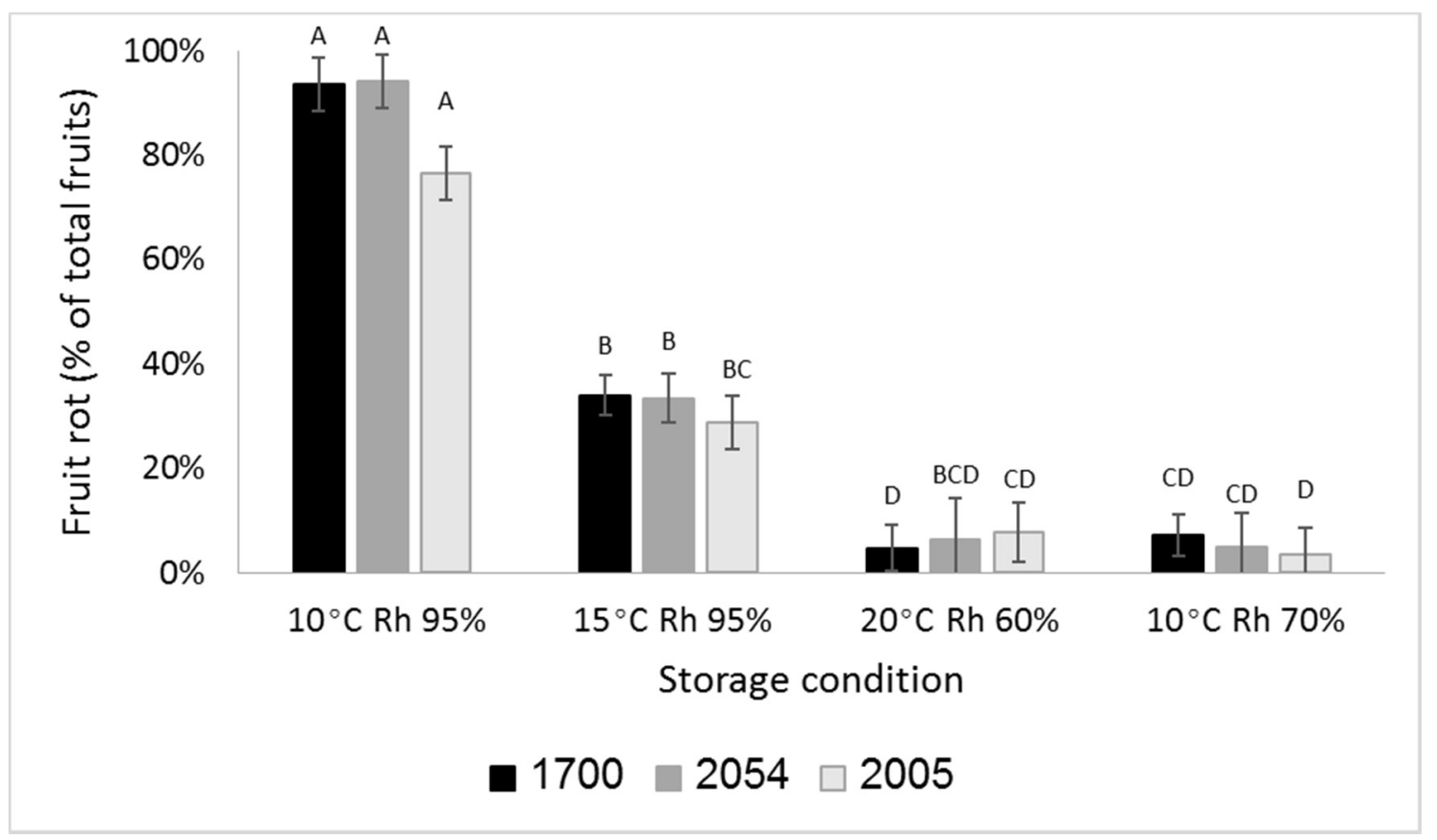

Figure 6. Fruit decay incidence under various storage conditions of the three hybrids (1700, 2054 and 2005). Rot incidences were recorded weekly. Cumulative data of 3 months of storage are presented. Each experiment was conducted at least 4 times (from fruits of 4 different harvests), each experiment included 2 repeats for each treatment. Bars indicate standard error. Two-component analysis is presented for cultivar and storage condition. Means without a common letter are significantly different (Tukey HSD, $\alpha=0.05$ ).

\subsubsection{Reducing Relative Air Humidity and Fruit Quality}

To assess the effect of storage on weight loss (WL), fruits were evaluated periodically (Figure 7). Storage at $20^{\circ} \mathrm{C} \mathrm{Rh} 60 \%$ resulted in more WL in fruits of Hybrids 1700 and 2054, within 1.5 months 
of storage, than the other storage conditions. After 1.5 months of storage, fruits of all cultivars lost $10-15 \%$ of their weight at $20^{\circ} \mathrm{C}$ whilst only $5-8 \%$ weight loss was observed for fruits stored at $10^{\circ} \mathrm{C}$ Rh $70 \%$ or $15{ }^{\circ} \mathrm{C}$. WL at these two storage conditions were similar for up to 2.5 months (ranging around $10 \% \mathrm{WL}$ ). WL was significantly higher after 3 months of storage, reaching $15 \%$ to $20 \% \mathrm{WL}$ of fruits stored at low humidity. Fruits of Hybrids 1700 and 2054 lost more percent weight during storage than those of Hybrid 2005. The weight of fruit stored at $10{ }^{\circ} \mathrm{C}$ Rh $95 \%$ was best maintained, as WL did not increase over $5 \%$ for all cultivars over a period of 3.5 months.
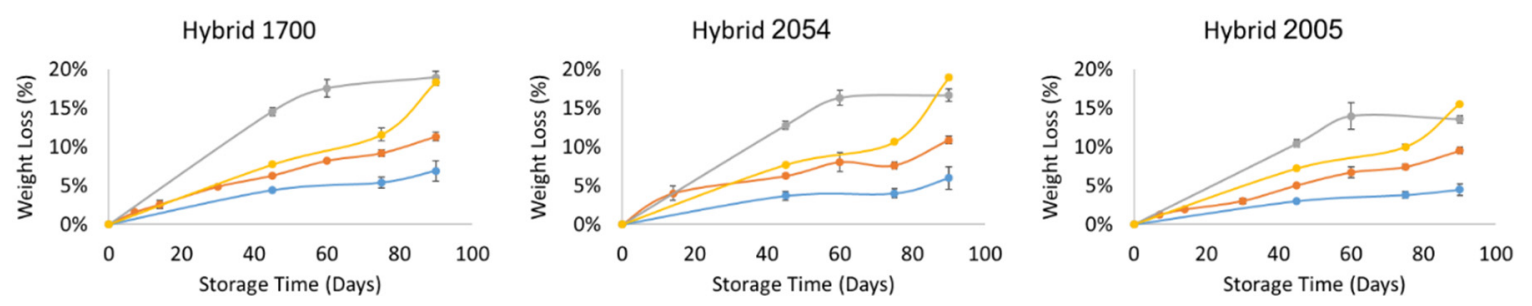

$\rightarrow 10^{\circ} \mathrm{CRh} 95 \%$

$\rightarrow 15{ }^{\circ} \mathrm{CRh} 95 \%$

$\rightarrow 20{ }^{\circ} \mathrm{CRh} 60 \%$

$\rightarrow 10{ }^{\circ} \mathrm{CRh} 70 \%$

Figure 7. Fruit weight loss under four storage conditions, by cultivar from one representative experiment. WL was evaluated periodically. Bars indicate standard error; $n=20$ fruits for each storage condition of each cultivar, for a total of 240 fruits.

\subsubsection{Storage at $20^{\circ} \mathrm{C}$ and $\mathrm{Rh} 60 \%$ Compared with $15^{\circ} \mathrm{C}$ and $95 \% \mathrm{Rh}$}

Fruits stored at $20^{\circ} \mathrm{C}$ Rh $60 \%$ were evaluated and compared with fruits stored at $15{ }^{\circ} \mathrm{C} 95 \% \mathrm{Rh}$ for their quality after 2 or 3 months. After 2 months, fruits stored at $20^{\circ} \mathrm{C} \mathrm{Rh} 60 \%$ showed much less decay and had similar levels of TSS, DW and flesh color to those of fruits stored at $15^{\circ} \mathrm{C}$ Rh $95 \%$ (Table 4). Nevertheless, storage at $20^{\circ} \mathrm{C}$ resulted in a significantly higher weight loss alongside a lightening of the rind color of all cultivars (Figure 8). The fading of the rind color was more pronounced for Hybrids 1700 and 2054 than for Hybrid 2005. Fruit firmness was not affected by the differing storage conditions, except for fruits of Hybrid 1700, which showed reduced fruit firmness. After 3 months of storage at 20 ${ }^{\circ} \mathrm{C}$ with $\mathrm{Rh} 60 \%$, fruits were too dehydrated in appearance to be marketable.

Results of hedonic taste tests performed after 2 months of storage indicated that fruit quality was perceived similarly for fruits of Hybrids 1700 and 2054 that were stored at $20^{\circ} \mathrm{C}$ as for $15^{\circ} \mathrm{C}$, although they were evaluated as slightly less sweet and more fibrous (Figure S4). Even though Hybrid 2005 retained its green rind color at $20^{\circ} \mathrm{C}$, fruits harvested at Harvest 1 were evaluated as significantly less sweet, less tasty and more fibrous than the fruits of the same Harvest that were stored at $15^{\circ} \mathrm{C}$. 


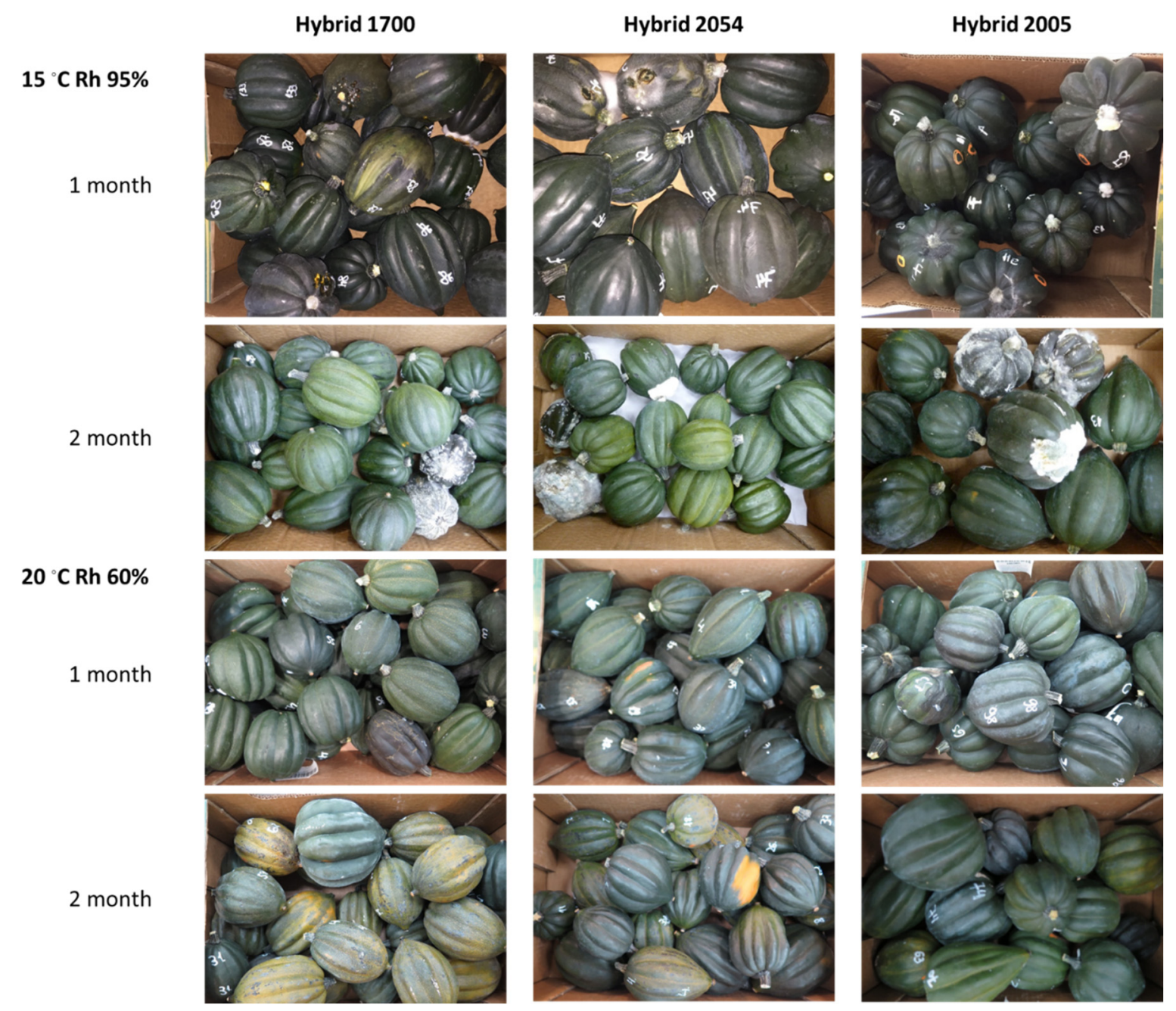

Figure 8. Fruits stored at $15{ }^{\circ} \mathrm{C}$ Rh $95 \%$ or $20{ }^{\circ} \mathrm{C}$ Rh $60 \%$ for 1 and 2 months.

\subsubsection{Cold Storage Preservation for 3 Months}

Fruits stored at either $10^{\circ} \mathrm{C}$ or $15^{\circ} \mathrm{C}$ were evaluated for their quality after 3 months of storage. Fruit decay as result of molds was significantly lower at $10^{\circ} \mathrm{C} \mathrm{Rh} 70 \%$ than fruits stored at $15^{\circ} \mathrm{C} \mathrm{Rh}$ $95 \%$ or $10{ }^{\circ} \mathrm{C}$ Rh $95 \%$ (Figure 9). Fruits stored at $10{ }^{\circ} \mathrm{C}$ Rh $70 \%$ showed similar levels of TSS, DW, rind color as well as flesh color as those of fruits stored at $15{ }^{\circ} \mathrm{C} \mathrm{Rh} 95 \%$ for the same time period (Table 5). Even though weight loss was greater at $10^{\circ} \mathrm{C} \mathrm{Rh} 70 \%$ and fruit firmness was lower, fruit quality remained high and the fruits were marketable. This was further validated by the hedonic taste test that showed similar effects of the two different storage conditions on fruit sweetness, texture and general acceptance, relative to the quality of fruits at harvest (Figure 10). Fruits of all cultivars were perceived as sweeter, more fibrous and slightly more bitter after storage relative to harvest time. Overall, the general impression was similar or higher after storage than at harvest time. 
Table 4. The effect of storage conditions and cultivar on acorn squash quality parameters after 2 months of cold storage.

\begin{tabular}{|c|c|c|c|c|c|c|c|c|}
\hline $\begin{array}{l}\text { Storage } \\
\text { Conditions }\end{array}$ & Hybrid & Decay (\%) & $\begin{array}{l}\text { Weight Loss } \\
(\%)\end{array}$ & $\begin{array}{l}\text { Rind Color } \\
\left(\mathrm{Hue}^{\circ}\right)\end{array}$ & $\begin{array}{c}\text { Flesh Color } \\
\left(\mathrm{a}^{*}\right)\end{array}$ & TSS (\%) & Dry Weight (\%) & Firmness (N) \\
\hline \multirow{3}{*}{$15^{\circ} \mathrm{C}$ Rh $95 \%$} & 1700 & $34.0 \mathrm{a}$ & $6.6 \mathrm{c}$ & $163 \mathrm{ab}$ & $10.4 \mathrm{a}$ & $15.5 \mathrm{a}$ & $26.6 \mathrm{a}$ & $173 a b$ \\
\hline & 2054 & $33.4 \mathrm{a}$ & $7.3 \mathrm{bc}$ & $204 \mathrm{a}$ & $8.2 \mathrm{a}$ & $18.4 \mathrm{a}$ & $25.4 \mathrm{a}$ & $187 \mathrm{a}$ \\
\hline & 2005 & $28.7 \mathrm{ab}$ & $5.1 \mathrm{c}$ & $198 \mathrm{a}$ & $8.0 \mathrm{a}$ & $15.7 \mathrm{a}$ & $20.4 \mathrm{a}$ & $151 \mathrm{c}$ \\
\hline \multirow{3}{*}{$20^{\circ} \mathrm{C}$ Rh $60 \%$} & 1700 & $4.8 \mathrm{c}$ & $13.0 \mathrm{a}$ & $131 \mathrm{~b}$ & $9.3 \mathrm{a}$ & $16.8 \mathrm{a}$ & $26.4 \mathrm{a}$ & $150 \mathrm{c}$ \\
\hline & 2054 & $6.3 \mathrm{bc}$ & $16.3 \mathrm{a}$ & $142 \mathrm{~b}$ & $9.8 \mathrm{a}$ & $17.4 \mathrm{a}$ & $19.7 \mathrm{a}$ & $182 \mathrm{a}$ \\
\hline & 2005 & $7.8 \mathrm{c}$ & $11.5 \mathrm{ab}$ & $174 \mathrm{ab}$ & $10.1 \mathrm{a}$ & $15.6 \mathrm{a}$ & $22.7 \mathrm{a}$ & $155 \mathrm{bc}$ \\
\hline $\mathrm{LSD}^{\mathrm{Z}}$ & & 5.91 & 1.27 & 15.6 & 1.34 & 1.15 & 2.45 & 6.7 \\
\hline \multicolumn{9}{|c|}{ Mean values at each temperature } \\
\hline $15^{\circ} \mathrm{C}$ Rh $95 \%$ & & $32.0 \mathrm{a}$ & $6.3 \mathrm{~b}$ & $188 \mathrm{a}$ & $8.9 \mathrm{a}$ & $16.5 \mathrm{a}$ & $24.1 \mathrm{a}$ & $170 \mathrm{a}$ \\
\hline $20^{\circ} \mathrm{C}$ Rh $60 \%$ & & $6.3 \mathrm{~b}$ & $13.6 \mathrm{a}$ & $149 \mathrm{~b}$ & $9.8 \mathrm{a}$ & $16.6 \mathrm{a}$ & $22.9 \mathrm{a}$ & $162 b$ \\
\hline LSD & & 3.8 & 0.82 & 9.1 & 0.81 & 0.68 & 1.41 & 3.8 \\
\hline \multicolumn{9}{|c|}{ Mean values of each cultivar } \\
\hline & 1700 & $19.4 \mathrm{a}$ & $9.7 \mathrm{ab}$ & $147 \mathrm{~b}$ & $9.9 \mathrm{a}$ & $16.1 \mathrm{ab}$ & $26.5 \mathrm{a}$ & $162 \mathrm{~b}$ \\
\hline & 2054 & $19.8 \mathrm{a}$ & $11.8 \mathrm{a}$ & $173 \mathrm{ab}$ & $9.0 \mathrm{a}$ & $17.9 \mathrm{a}$ & $22.6 \mathrm{ab}$ & $185 \mathrm{a}$ \\
\hline & 2005 & $18.2 \mathrm{a}$ & $8.3 \mathrm{~b}$ & $186 \mathrm{a}$ & $9.0 \mathrm{a}$ & $15.6 \mathrm{~b}$ & $21.5 \mathrm{~b}$ & $153 b$ \\
\hline & LSD & 4.2 & 1.17 & 11.2 & 0.99 & 0.84 & 1.73 & 4.7 \\
\hline \multicolumn{9}{|c|}{ Table of Variance (F-value) } \\
\hline \multirow{3}{*}{\multicolumn{2}{|c|}{$\begin{array}{c}\text { Temperature }(\mathrm{Tr}) \\
\text { Cultivar }(\mathrm{Cv}) \\
\operatorname{Tr} \times \mathrm{Cv}\end{array}$}} & $* * *$ & $* * *$ & $* * *$ & NS & NS & NS & $*$ \\
\hline & & NS & $*$ & $* *$ & NS & $*$ & $*$ & $* * *$ \\
\hline & & NS & NS & NS & NS & NS & NS & * \\
\hline
\end{tabular}

$\mathrm{Z}_{\mathrm{LSD}}$, Least significant differences at $\alpha=0.05$. Hue ${ }^{\circ}$, Hue angle in CIE Lch color space; ${ }^{*}$, Red/Green Value in CIE $\mathrm{L}^{*} \mathrm{a}^{*} \mathrm{~b}^{*}$ color space. Means within columns followed by the same letter are not significantly different at $p \leq 0.05$, based on the least significant differences test, ${ }^{* * *}, * *, *$, NS indicate statistical significance at $p \leq 0.001,0.01,0.05$ and not significant, respectively. 
Table 5. The effect of storage conditions and cultivar on acorn squash quality parameters after 3 months of cold storage.

\begin{tabular}{|c|c|c|c|c|c|c|c|c|}
\hline $\begin{array}{l}\text { Storage } \\
\text { Conditions }\end{array}$ & Cultivar & Decay (\%) & $\begin{array}{l}\text { Weight Loss } \\
(\%)\end{array}$ & $\begin{array}{l}\text { Rind Color } \\
\left(\mathrm{Hue}^{\circ}\right)\end{array}$ & $\begin{array}{c}\text { Flesh Color } \\
\left(\mathrm{a}^{*}\right)\end{array}$ & TSS (\%) & Dry Weight (\%) & Firmness (N) \\
\hline \multirow{3}{*}{$15^{\circ} \mathrm{C} \operatorname{Rh} 95 \%$} & 1700 & $34.0 \mathrm{a}$ & $11.9 \mathrm{bcd}$ & $208 \mathrm{~b}$ & $10.5 \mathrm{ab}$ & $18.7 \mathrm{ab}$ & $24.2 \mathrm{a}$ & $164 \mathrm{a}$ \\
\hline & 2054 & $33.4 \mathrm{a}$ & $11.1 \mathrm{~cd}$ & 243 a & $8.5 \mathrm{~b}$ & $18.1 \mathrm{ab}$ & $22.9 \mathrm{ab}$ & $169 a$ \\
\hline & 2005 & $28.7 \mathrm{a}$ & $10.0 \mathrm{~d}$ & $245 \mathrm{a}$ & $7.3 \mathrm{~b}$ & $15.0 \mathrm{c}$ & $16.9 \mathrm{c}$ & $148 \mathrm{a}$ \\
\hline \multirow{3}{*}{$10^{\circ} \mathrm{C}$ Rh $70 \%$} & 1700 & $7.2 \mathrm{~b}$ & $14.1 \mathrm{ab}$ & $222 \mathrm{ab}$ & $12.3 \mathrm{a}$ & $19.7 \mathrm{a}$ & $24.2 \mathrm{a}$ & $151 \mathrm{a}$ \\
\hline & 2054 & $5.0 \mathrm{~b}$ & $14.8 \mathrm{a}$ & $233 \mathrm{ab}$ & $7.7 \mathrm{~b}$ & $17.2 \mathrm{abc}$ & $21.0 \mathrm{abc}$ & $146 \mathrm{ab}$ \\
\hline & 2005 & $3.6 \mathrm{~b}$ & $12.6 \mathrm{abc}$ & $234 \mathrm{ab}$ & $8.3 \mathrm{~b}$ & $16.5 \mathrm{bc}$ & 19.3 bc & $124 \mathrm{~b}$ \\
\hline $\operatorname{LSD}^{\mathrm{Z}}$ & & 6.5 & 0.9 & 9.4 & 1.2 & 0.93 & 1.40 & 8.2 \\
\hline \multicolumn{9}{|c|}{ Mean values at each temperature- $R h$} \\
\hline $15^{\circ} \mathrm{C}$ Rh $95 \%$ & & $32.0 \mathrm{a}$ & $11.0 \mathrm{~b}$ & $232 \mathrm{a}$ & $8.8 \mathrm{a}$ & $17.8 \mathrm{a}$ & $21.3 \mathrm{a}$ & $160 \mathrm{a}$ \\
\hline $10^{\circ} \mathrm{C}$ Rh $70 \%$ & & $5.3 \mathrm{~b}$ & $13.8 \mathrm{a}$ & $229 a$ & $9.4 \mathrm{a}$ & $17.2 \mathrm{a}$ & $21.5 \mathrm{a}$ & $140 \mathrm{~b}$ \\
\hline LSD & & 3.3 & 0.54 & 5.3 & 0.69 & 0.54 & 0.83 & 4.8 \\
\hline \multicolumn{9}{|c|}{ Mean values of each cultivar } \\
\hline & 1700 & $20.6 \mathrm{a}$ & $13.0 \mathrm{a}$ & $215 b$ & $11.4 \mathrm{a}$ & $19.2 \mathrm{a}$ & $24.2 \mathrm{a}$ & $158 \mathrm{a}$ \\
\hline & 2054 & $19.2 \mathrm{a}$ & $12.9 \mathrm{a}$ & $238 \mathrm{a}$ & $8.1 \mathrm{~b}$ & $17.6 \mathrm{a}$ & $21.9 \mathrm{a}$ & $158 \mathrm{a}$ \\
\hline & 2005 & $16.2 \mathrm{a}$ & $11.3 \mathrm{~b}$ & $239 a$ & $7.8 \mathrm{~b}$ & $15.8 \mathrm{~b}$ & $18.1 \mathrm{~b}$ & $136 \mathrm{~b}$ \\
\hline & LSD & 4.0 & 0.64 & 6.7 & 0.86 & 0.67 & 1.04 & 5.7 \\
\hline \multicolumn{9}{|c|}{ Table of Variance (F-value) } \\
\hline \multirow{3}{*}{\multicolumn{2}{|c|}{$\begin{array}{c}\text { Temperature-Rh (Tr) } \\
\text { Cultivar (Cv) } \\
\operatorname{Tr} \times \mathbf{C v}\end{array}$}} & $* * *$ & $* * *$ & NS & NS & NS & NS & $* * *$ \\
\hline & & NS & * & $* * *$ & $* * *$ & $* * *$ & $* * *$ & $* * *$ \\
\hline & & NS & NS & NS & NS & NS & NS & NS \\
\hline
\end{tabular}

${ }^{\mathrm{Z}}$ LSD, Least significant differences at $\alpha=0.05$. Hue ${ }^{\circ}$, Hue angle in CIE Lch color space; ${ }^{*}$, Red/Green Value in CIE L*a* ${ }^{*}$ color space. Means within columns followed by the same letter are not significantly different at $p \leq 0.05$, based on the least significant differences test, $* * * *$, NS indicate statistical significance at $p \leq 0.001,0.05$ and not significant, respectively. 

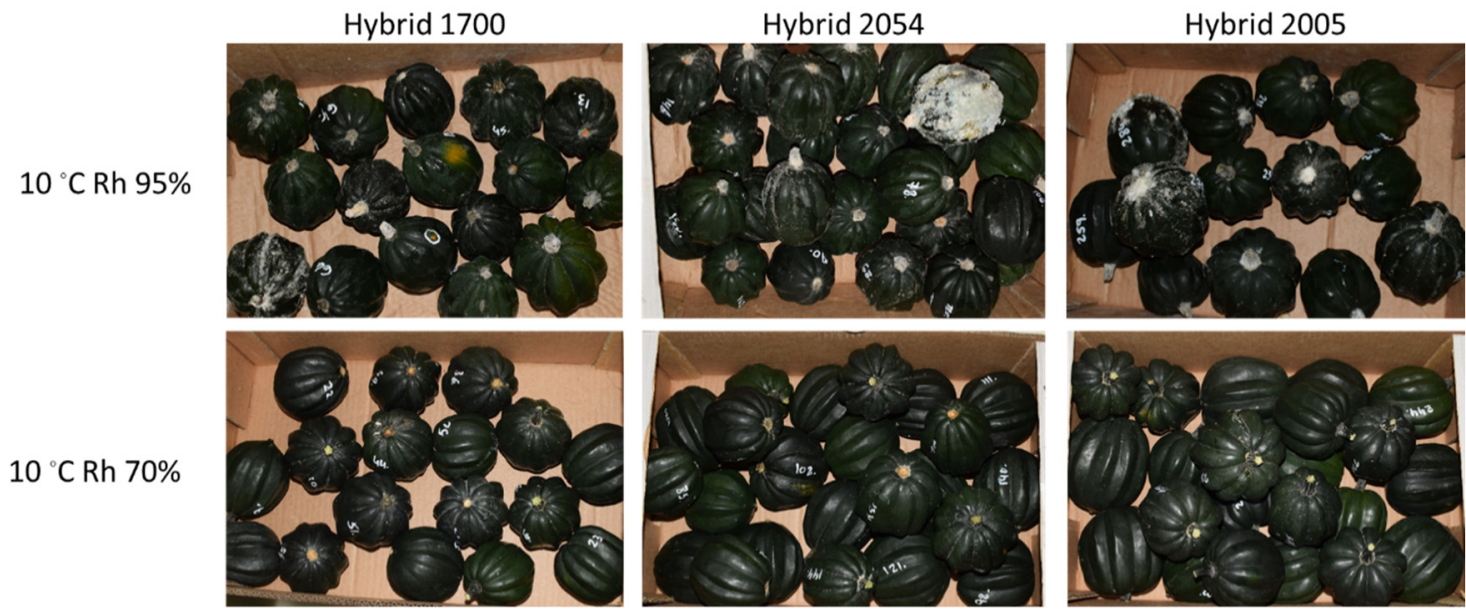

$15^{\circ} \mathrm{C}$ Rh $95 \%$
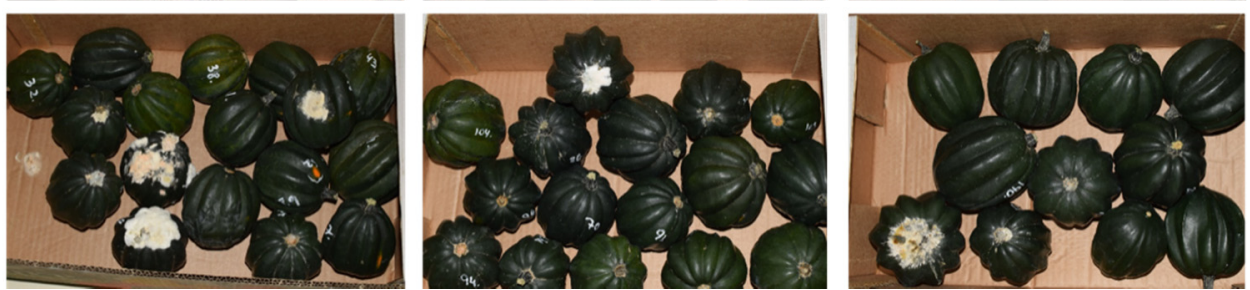

Figure 9. Fruits stored at $15{ }^{\circ} \mathrm{C} \mathrm{Rh} 95 \%, 10{ }^{\circ} \mathrm{C}$ Rh $95 \%$ or $10{ }^{\circ} \mathrm{C}$ Rh $70 \%$ for 3 months.
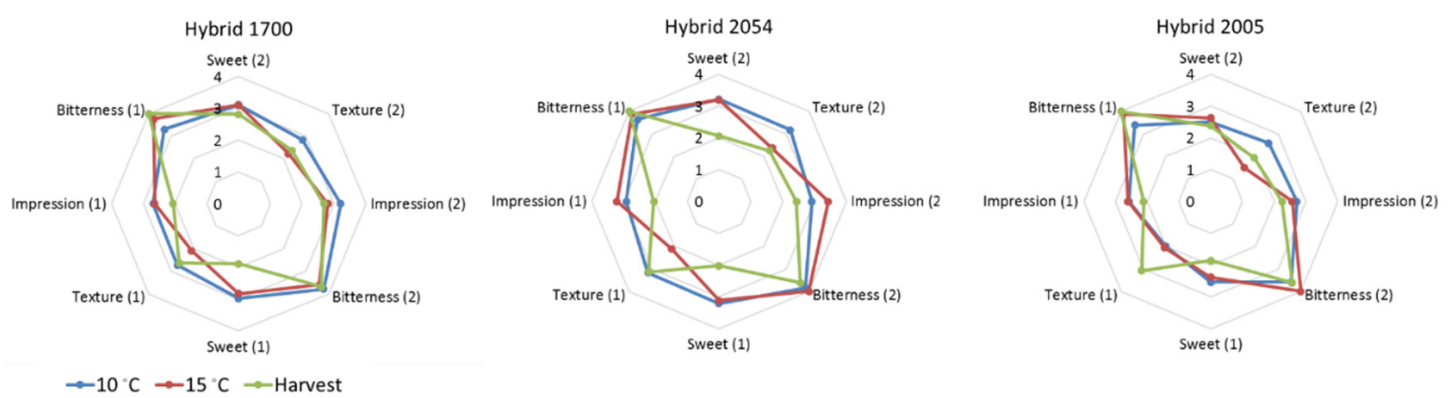

Figure 10. Hedonic test of the fruit flesh of three Hybrids 1700, 2054 and 2005, from two harvests (Harvest 1 and Harvest 2), upon harvest or after three months of storage at $10^{\circ} \mathrm{C} \mathrm{Rh} 70 \%$ or $15^{\circ} \mathrm{C} \mathrm{Rh}$ 95\%. Results of sweetness (Sweet), texture, general impression (Impression) and bitterness at harvest or at the end of storage are presented. $1 / 2$ indicate harvest number. The score of each parameter was 1 to 4: Sweetness 1-not sweet, 2-slightly sweet, 3-moderately sweet, 4-very sweet. Texture 1-very fibrous, 2-fibrous, 3-slightly fibrous, 4-very smooth. General impression 1-not tasty, 2-slightly tasty, 3-moderately tasty, 4-very tasty. Bitterness 1-very bitter, 2-moderately bitter, 3-slightly bitter, 4-not bitter.

\section{Discussion}

Acorn squash are a nutritious fruit vegetable appreciated for their attractive appearance, convenient size, culinary versatility, and long storage life [3,6]. Acorn squash are a good source of vitamin C, potassium, magnesium and folic acid [14-16]. Their yellow-orange flesh is also an excellent source of carotenoids, mostly beta-carotene and lutein $[17,18]$.

The acorn squash grown in Israel are almost exclusively of the new black-green-fruited, ultrasweet 'Table Sugar' (Hybrid 1700), 'Table Confection' (Hybrid 2005), and 'Table Pastry' (Hybrid 2054), developed by the Agricultural Research Organization [7]. 'Table Sugar', which was introduced in 2007, became popular after concerted efforts by a licensed vendor, Origene Seeds, to connect among growers, wholesalers, retailers, chefs, and consumers, the whole marketing chain, for introducing what was for Israel an entirely new product. Since its introduction, the area and production of 'Table 
Sugar' has expanded constantly in Israel. It is recognized by consumers as a premium product and they expect supreme quality for the high price they pay for it, which is more than double that of other pumpkins and winter squash. To legally safeguard this new product against cheaper, inferior imitations, invariably imported, the vendor trademarked the local Hebrew name for this product, Dela'at 'Armonim.

The yields of 'Table Sugar' were low, and this is the major reason for the high price of its fruits on the market. Winter squash and pumpkins having high dry matter content produce lower yields, by fresh weight, than those low in dry matter and hence of lower quality [5]. Hybrid 2005 and Hybrid 2054, which were released in 2017, were bred to bear larger fruits, leading to higher yields for farmers, without sacrificing much in dry matter content and quality. The results presented in Table 3 show that these newer cultivars have higher yields and larger fruits than 'Table Sugar', but produce the same number of fruits. At harvest, dry matter content of the fruit flesh was very high for all three hybrids, $22.6 \%$ for 'Table Sugar', even higher 24.6\% for Hybrid 2054, and 19.7\%, for the largest-fruited Hybrid 2005 (Table S1). On the day of harvest, total soluble solids were quite high too, with 'Table Sugar' and Hybrid 2054 averaging over 15\% and Hybrid 2005 13.5\% (Table S1). During the first two years, the fruits of the first harvest were 60 days or more past anthesis (dpa) (Table 1). Even at this late stage of development, the fruits of the three hybrids averaged over $20 \%$ dry weight. Having both, high dry matter content and high TSS simultaneously in the fruit flesh may be unique to these three cultivars. Fruits of most acorn squash cultivars attain 15\% dry matter at their peak, 25-30 dpa, at which time they have $7 \%$ TSS $[5,19]$. Improved, sweet acorn squash in the U.S.A. have reached peak dry matter of $20-21 \%$ at $25 \mathrm{dpa}$, at which time they also average 6-7\% TSS [4]. At $45 \mathrm{dpa}$, fruits of these same improved cultivars achieve $13 \%$ TSS at harvest and $14 \%$ TSS after 10 days storage at $21{ }^{\circ} \mathrm{C}$ [19]. The widely different growing conditions between Israel and the U.S.A. make comparisons difficult, as it is unknown if the causes for the differences in dry matter and TSS are mostly genetically or environmentally determined. However, 'Table Sugar' has given similar results for TSS in the present experiments (Table S1) and in field-grown, spring-summer crops in Israel [7]. In this light, it would be worthwhile to check and compare dry matter content as well as total soluble solids at closer intervals over the course of fruit development under various growing conditions in different seasons.

The newer cultivars, especially Hybrid 2005, showed superior traits over 'Table Sugar' by having significantly higher yields (Table 3), blacker rind color (Table S1), and less weight loss during cold storage (Table 5). Although Hybrid 2005 performed better in storage, maintaining its black-green rind color and being less prone to fungal rots, its TSS and hedonistic impression were lower than those of the other two cultivars (Figure 10 and Figure S4). Although higher yields of a cultivar are an obvious advantage to the farmer, consumers demand the best tasting fruits and in Israel, it seems, also prefer fruits that are not so large.

During fruit development and ripening, sugars, starch and carotenoids accumulate and significantly affect fruit sweetness, texture and nutritional values, respectively [20-22]. Fruit acidity in pumpkin and squash is low $(0.04-0.3 \%$ of $\mathrm{FW}, \mathrm{pH}$ 6.8) and has no effect on the fruit sensory quality $[23,24]$. Our data indicate that when well-grown and properly stored, the fruits of the three new acorn squash cultivars can accumulate on average as much as 20\% TSS at harvest and in storage (Table 4, Table 5, and Table S1), and thus are a very sweet vegetable indeed. Longer storage periods may result in bitterness that affects acceptance. Interestingly, our unpublished data indicate that during cooking, fruit TSS is further increased, probably due to starch degradation during the processing and either steaming or microwave cooking.

During ripening and postharvest storage, the fruit flesh intensifies in color as carotenoids accumulate [12]. Here we observed that the major carotenoid of ripe acorn squash fruits was $\beta$-carotene (accumulating up to $23 \mu \mathrm{g} / \mathrm{g} \mathrm{FW}$ ), while lutein content was low (Figure S3). These results are consistent with previously described carotenoid levels of acorn squash [21] and of other squash having orange flesh [11]. Two other carotenoid peaks were detected which might be xanthophylls, but further research is required to identify them. 
In order to promote the growth of acorn squash in Israel during winter, we have evaluated trellis cultivation in a netted greenhouse, which enabled three harvests per season with a $50 \%$ increase in yield (Avraham and Ziv, unpublished). However, these growing conditions resulted in a significant increase in decay incidence of the fruits during storage. While chemical pesticides can provide effective control of fungal rots during storage, the potential risk to humans and environment posed by chemical control and the growing awareness of the customers to fruit quality and safety urged us to seek non-hazardous means to control postharvest rots of fruits caused by phytopathogenic molds. For this purpose, we previously examined the potential of precise steam treatments to prevent fruit rot of acorn squash and reduce fruit losses during long-term cold storage, which was found to be effective but had a negative effect on fruit appearance [25]. In addition, it was shown that hot water rinsing and brushing (HWRB) can significantly reduce the decay rate of summer, field-grown acorn squash fruits when stored for 3.5 months at $15{ }^{\circ} \mathrm{C}$ [9]. However, HWRB was less effective in preventing fruit decay when the fruits were grown in a greenhouse for harvest during the winter (Figure 6). This may be due to a significantly higher inoculum load of fungal spores already attached to the fruits in the greenhouse. Thus, under these growing conditions, more effective means of controlling fruit rots during storage are required.

The optimum storage temperature for squash is $10-15{ }^{\circ} \mathrm{C}$. Storage temperatures lower than $10^{\circ} \mathrm{C}$ may cause chilling injury, depending upon the degree of field acclimation to cold temperatures experienced by the squash [26]. Previously, from spring-summer field-grown 'Table Sugar', $15^{\circ} \mathrm{C}$ appeared to be the best storage temperature to keep the fruits for 3.5 months [9]. At $10^{\circ} \mathrm{C}$, although fruits lost less weight and were much greener, decay incidence was significantly higher. Our results clearly indicate similar effects of storage temperature for all three cultivars tested, although fruits of Hybrid 2005 were slightly more adapted to $10^{\circ} \mathrm{C}$ storage conditions (Figure 6). Interestingly, lowering the humidity at $10^{\circ} \mathrm{C}$ significantly reduced decay incidence, indicating humidity is a critical factor affecting acorn-squash susceptibility to fungal infection. Maintaining low humidity is a common practice of grain storage to prevent mold, however it is rarely applied to fresh produce due to the negative effect on perishable food quality [27]. Weight loss is a major concern when storing fruits at low relative humidity. And indeed, fruits of all cultivars, but mostly the smaller fruits of Hybrids 1700 and 2054 , lost up to $10 \%$ of their weight at harvest when stored at $10{ }^{\circ} \mathrm{C} \mathrm{Rh} 70 \%$ (Figure 7), however their external and sensory quality remained high for up to 3 months of storage with significantly less fruit decay (Table 5, Figure 9). Furthermore, storage at $20{ }^{\circ} \mathrm{C}$ Rh $60 \%$ maintained reasonable fruit quality for as much as two months (Table 4, Figure 8). These findings can be useful for developing a more precise storage protocol according to the required storage duration.

In recent years, acorn squash has become a familiar, premium product in Israel because of its distinctive attractive appearance, convenient size, and supreme quality. Presently, we have described and quantified fruit quality and storability of the three acorn squash cultivars grown in Israel, under protected conditions in winter. Over three consecutive years, we identified differences among the cultivars in fruit sensory quality as well as susceptibility to fungal rots during storage. Together with providing solid data regarding cultivar productivity, we have developed a protocol for postharvest storage of these acorn squash, to facilitate marketing over an extended period of time after harvest in order to meet the expanding market demand for this product.

\section{Conclusions}

The three acorn squash cultivars developed in Israel are well-suited to growing in greenhouses in fall and winter as well as in the open field in the spring and summer. The first cultivar to be developed, 'Table Sugar', bears small fruits and has the lowest yield, but has the most intense flesh color and maintains a high dry matter content of $24 \%$ and TSS of $19 \%$, even after three months of storage. The new 'Table Confection' bears the largest fruits, has the highest yields and tends to lose less weight during storage, but has somewhat lower dry matter and carotenoid contents, and lower TSS of the fruit flesh. The new 'Table Pastry' bears fruits of intermediate size and has yields intermediate 
between the other two cultivars, and nearly equals 'Table Sugar' in dry matter content and TSS, but not flesh color.

Fruits of the three acorn squash cultivars are highly susceptible to fungal rots during cold storage. Combining low temperature storage with relatively low humidity $\left(10^{\circ} \mathrm{C} \mathrm{Rh} 70 \%\right)$ reduces fruit-rot incidence while maintaining high fruit quality, and thus has a good potential to serve for long-term storage of acorn squash grown under protected conditions in the winter. This prolonged storage of acorn squash will allow controlled, gradual marketing over an extended period of time to maintain supply at a high price level for farmers and open the possibility for export of acorn squash to overseas markets.

Supplementary Materials: The following are available online at http://www.mdpi.com/2073-4395/10/9/1443/s1, Table S1: Fruit quality parameters of acorn squash fruits at harvest, according to cultivar and harvest sequence; Figure S1: Fruit weight by cultivar and harvest sequence over three years; Figure S2: Yield by cultivar and harvest sequence over three years; Figure S3: Identification and quantification of acorn squash carotenoids; Figure S4: Hedonic tests of three acorn squash cultivars from two separate harvests (Harvest 1 and Harvest 2) after two months of storage, at $15{ }^{\circ} \mathrm{C}$ Rh $95 \%$ and $20{ }^{\circ} \mathrm{C} \mathrm{Rh} 60 \%$.

Author Contributions: Conceptualization, C.Z., L.A., H.A.; Methodology, A.A., F.Y., G.R., H.A., M.Z.P., S.A.-T.; Data analysis, A.A., L.A., C.Z.; writing, A.A., C.Z., H.S.P., E.F. All authors have read and agreed to the published version of the manuscript.

Funding: This research was funded by the Israeli Vegetable Council 2017-2019.

Acknowledgments: We thank Yaakov Tadmor and Ayala Meir for the HPLC analysis of carotenoids and Origene Seeds (Giv'at Brenner, Israel) for providing the seeds for the experiment.

Conflicts of Interest: The authors declare no conflict of interest.

\section{References}

1. Paris, H.S.; Burger, Y.; Schaffer, A.A. Genetic variability and introgression of horticulturally valuable traits in squash and pumpkins of Cucurbita pepo. Isr. J. Plant Sci. 2006, 54, 223-231. [CrossRef]

2. Paris, H.S. History of the cultivar-groups of Cucurbita pepo. In Horticultural Reviews; John Wiley \& Sons: Hoboken, NJ, USA, 2000; Volume 25, pp. 71-170.

3. Paris, H.S. A proposed subspecific classification for Cucurbita pepo. Phytologia 1986, 61, 133-138.

4. Loy, J.B. Interaction of harvest time and storage on attributes of eating quality in acorn squash. HortScience 2006, 41, 496. [CrossRef]

5. Loy, J.B. Morpho-physiological aspects of productivity and quality in squash and pumpkins (Cucurbita spp.). Crit. Rev. Plant Sci. 2004, 23, 337-363. [CrossRef]

6. Paris, H.S. Germplasm enhancement of Cucurbita pepo (pumpkin, squash, gourd: Cucurbitaceae): Progress and challenges. Euphytica 2016, 208, 415-438. [CrossRef]

7. Paris, H.S.; Godinger, D. Sweet acorn squash, a new vegetable on the Israeli market. Acta Hortic. 2016, 451-456. [CrossRef]

8. Gaba, V.; Zelcer, A.; Gal-On, A. Cucurbit biotechnology-the importance of virus resistance. Vitr. Cell. Dev. Biol. Plant 2004, 40, 346-358. [CrossRef]

9. Chalupowicz, D.; Alkalai-Tuvia, S.; Zaaroor-Presman, M.; Fallik, E. The potential use of hot water rinsing and brushing technology to extend storability and shelf life of sweet acorn squash (Cucurbita pepo L.). Horticulturae 2018, 4, 19. [CrossRef]

10. Itle, R.A.; Kabelka, E.A. Correlation between $L^{*} a^{*} b^{*}$ color space values and carotenoid content in pumpkins and squash (Cucurbita spp.). HortScience 2009, 44, 633-637. [CrossRef]

11. Tadmor, Y.; Paris, H.S.; Meir, A.; Schaffer, A.A.; Lewinsohn, E. Dual role of the pigmentation gene B in affecting carotenoid and vitamin E content in squash (Cucurbita pepo) mesocarp. J. Agric. Food Chem. 2005, 53, 9759-9763. [CrossRef]

12. Zhang, M.K.; Zhang, M.P.; Mazourek, M.; Tadmor, Y.; Li, L. Regulatory control of carotenoid accumulation in winter squash during storage. Planta 2014, 240, 1063-1074. [CrossRef] [PubMed]

13. Tadmor, Y.; Larkov, O.; Meir, A.; Minkoff, M.; Lastochkin, E.; Edelstein, M.; Levin, S.; Wong, J.; Rocheford, T.; Lewinsohn, E. Reversed-phase high performance liquid chromatographic determination of vitamin $\mathrm{E}$ components in maize kernels. Phytochem. Anal. 2000, 11, 370-374. [CrossRef] 
14. Aliu, S.; Rusinovci, I.; Fetahu, S.; Salihu, S.; Zogaj, R. Nutritive and mineral composition in a collection of Cucurbita pepo L grown in Kosova. Food Nutr. Sci. 2012, 3, 634.

15. Gharibzahedi, S.M.T.; Jafari, S.M. The importance of minerals in human nutrition: Bioavailability, food fortification, processing effects and nanoencapsulation. Trends Food Sci. Technol. 2017, 62, 119-132. [CrossRef]

16. Šlosár, M.; Mezeyová, I.; Hegedúsová, A.; Hegedús, O. Quantitative and qualitative parameters in Acorn squash cultivar in the conditions of the Slovak Republic. Potravin. Slovak J. Food Sci. 2018, 12, 91-98. [CrossRef]

17. Azevedo-Meleiro, C.H.; Rodriguez-Amaya, D.B. Qualitative and quantitative differences in carotenoid composition among Cucurbita moschata, Cucurbita maxima, and Cucurbita pepo. J. Agric. Food Chem. 2007, 55, 4027-4033. [CrossRef]

18. Murkovic, M.; Mülleder, U.; Neunteufl, H. Carotenoid content in different varieties of pumpkins. J. Food Compos. Anal. 2002, 15, 633-638. [CrossRef]

19. Loy, J.B. Harvest period and storage affect biomass partitioning and attributes of eating quality in acorn squash (Cucurbita pepo). In Cucurbitaceae Proceedings; Universal Printing \& Publishing: Raleigh, NC, USA, 2006; pp. 568-577.

20. Schaffer, A.A.; Paris, H.S. Melons, Squashes, and Gourds. In Reference Module in Food Science; Elsevier: Amsterdam, The Netherlands, 2016.

21. Wyatt, L.E.; Strickler, S.R.; Mueller, L.A.; Mazourek, M. Comparative analysis of Cucurbita pepo metabolism throughout fruit development in acorn squash and oilseed pumpkin. Hortic. Res. 2016, 3, 16045. [CrossRef]

22. Corrigan, V.K.; Irving, D.E.; Potter, J.F. Sugars and sweetness in buttercup squash. Food Qual. Prefer. 2000, 11, 313-322. [CrossRef]

23. Jacobo-Valenzuela, N.; de Jesus Zazueta-Morales, J.; Gallegos-Infante, J.A.; Aguilar-Gutierrez, F.; Camacho-Hernandez, I.L.; Rocha-Guzman, N.E.; Gonzalez-Laredo, R.F. Chemical and physicochemical characterization of winter squash (Cucurbita moschata D.). Not. Bot. Horti Agrobot. Cluj Napoca 2011, 39, 34-40. [CrossRef]

24. Culpepper, C.W.; Moon, H.H. Differences in the composition of the fruits of Cucurbita varieties at different ages in relation to culinary use. J. Agric. Res. 1945, 71, 111-136.

25. Adeeko, A.; Yudelevich, F.; Regev, R.; Avraham, L.; Alkalai-Tuvia, S.; Paris, H.S.; Fallik, E.; Ziv, C. The effect of postharvest treatments on produce losses during long-term storage of acorn squash. In Proceedings of the 5th International Symposium on Postharvest Pathology. Acta Hortic.. (in press).

26. Loy, J.B. The nuts and bolts of fruit quality in cucurbits. In Proceedings of the New England Vegetable and Fruit Conference, Manchester, NH, USA, 17-19 December 2013; Volume 17, pp. 201-204.

27. Bradford, K.J.; Dahal, P.; van Asbrouck, J.; Kunusoth, K.; Bello, P.; Thompson, J.; Wu, F. The dry chain: Reducing postharvest losses and improving food safety in humid climates. Trends Food Sci. Technol. 2018, 71, 84-93. [CrossRef]

(C) 2020 by the authors. Licensee MDPI, Basel, Switzerland. This article is an open access article distributed under the terms and conditions of the Creative Commons Attribution (CC BY) license (http://creativecommons.org/licenses/by/4.0/). 